\title{
Trichomonas vaginalis infection and the diagnostic significance of detection tests among Ghanaian outpatients
}

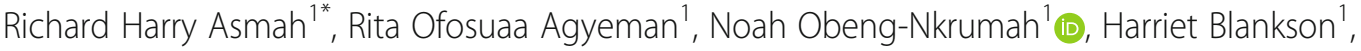 \\ Georgina Awuah-Mensah², Momodou Cham ${ }^{3}$, Listowell Asare ${ }^{3}$ and Patrick Ferdinand Ayeh-Kumi ${ }^{1}$
}

\begin{abstract}
Background: There is little data on Trichomonas vaginalis infection in Ghana. This study evaluated the prevalence of trichomoniasis using different diagnostic methods and determined the risk factors for infection in patients.

Methods: A structured questionnaire was administered. Vaginal swabs, urethral swabs and urine specimens were obtained from consenting patients; and the samples processed following standard protocols. The presence of $T$. vaginalis was determined using wet mount microscopy and polymerase chain reaction (PCR) as gold standard. We also assessed the diagnostic performance the JD's Trichomonas $V^{\circledR}$ rapid antigen test to inform clinical practice.

Results: The PCR assay detected T. vaginalis positivity in 64 of 150 patients $(42.6,95 \% \mathrm{Cl}: 35.0,50.6)$ including all positive samples of wet mount microscopy and JD's Trichomonas $V^{\otimes}$ test. Wet mount microscopy showed low sensitivity (31.6\%), high specificity (100\%), moderate positive predictive value (75.0\%), moderate positive likelihood ratio (3.0), and weak agreement (Cohen's kappa, 0.283) with PCR assay. The JD's Trichomonas V ${ }^{\otimes}$ test displayed lower sensitivity (25.0\%), specificity (83.3\%), and weaker measure of agreement (Cohen's kappa, 0.233) with PCR. In multivariate analysis, the strongest independent predictor for T. vaginalis was female gender [adjusted odds ratio (AOR), 24.89; 95\% confidence interval (Cl): 10.58, 51.21; P-value<0.001]. Knowledge of STI showed a protective effect against infection with the parasite (AOR, 0.13; 95\%Cl: 0.07, 0.29; $P$-value< 0.017$)$.

Conclusion: The sensitivity of wet mount microscopy was low for T. vaginalis screening in our region. The JD's Trichomonas $V^{\otimes}$ test should not be considered as an alternative test. We recommend mandatory PCR assay for confirmation of negative wet mount results.
\end{abstract}

Keywords: Ghana, Trichomoniasis, Wet mount, Polymerase chain reaction, Risk factors

\section{Background}

Trichomoniasis is a common sexually transmitted infection (STI) caused by the protozoan parasite Trichomonas vaginalis. The highest prevalence of trichomoniasis has been reported from resource-limited countries and among deprived populations in developed countries [1, 2]. Of the estimated 153 million cases of trichomoniasis, $25.64 \%$ are from the African [1, 3]. Trichomoniasis is mainly transmitted by sexual intercourse with an infected person and affects the

\footnotetext{
*Correspondence: rhasmah@chs.edu.gh

'Department of Medical Laboratory Sciences, School of Biomedical and

Allied Health Sciences, University of Ghana, Korle-bu, Accra, Ghana

Full list of author information is available at the end of the article
}

urogenital system, vagina, and urethra $[4,5]$. The clinical presentations of the infection in women include yellowish-green frothy vaginal discharge with vulvar irritation which may be confused with bacterial vaginitis, whereas infected men may briefly have urethral irritation, mild discharge, or slight burning after urination or ejaculation [3, 6-9]. Factors such as low level of education, poor hygiene, low socio-economic status, and multiple sexual partners have been associated with high prevalence of trichomoniasis [10,11].

There is paucity of data on $T$. vaginalis infection in Ghana [12, 13]. The few available studies were conducted among women. And most of these studies were performed with wet mount microscopy. Wet mount

(c) The Author(s). 2018 Open Access This article is distributed under the terms of the Creative Commons Attribution 4.0 International License (http://creativecommons.org/licenses/by/4.0/), which permits unrestricted use, distribution, and reproduction in any medium, provided you give appropriate credit to the original author(s) and the source, provide a link to the Creative Commons license, and indicate if changes were made. The Creative Commons Public Domain Dedication waiver (http://creativecommons.org/publicdomain/zero/1.0/) applies to the data made available in this article, unless otherwise stated. 
microscopy is reported to have low sensitivity of 45$60 \%$ compared with polymerase chain reaction (PCR) tests $[14,15]$. Consequently, the occurrence of trichomoniasis and its associated public health implications in Ghana may be underestimated. Other methods such as culture are recommended but it takes a long time for diagnosis and still requires expert microscopy. Simple-to-perform rapid diagnostic tests are emerging globally as the preferred point-of-care diagnosis for protozoan infections albeit with varying sensitivities compared to wet-mount. The JD's Trichomonas $\mathrm{V}^{\circ}$ antigen-based rapid diagnostic strip test Biotech $^{\mathrm{mx}}$ Corp., China) that was recently introduced in our district but with no data on its reliability. To inform practice, we assessed the diagnostic performance of JD's Trichomonas $\mathrm{V}^{\circ}$ test for $T$. vaginalis infections, compared to wet mount microscopy, and using PCR as the gold standard. We also report on the associated risk factors for trichomoniasis in our setting.

\section{Methods}

\section{Study settings}

This study was conducted at the Comboni Hospital in the South Tongu District of Ghana. The District has an estimated population of 86,000 with an annual growth rate of $2.5 \%$ [16]. The hospital has an annual outpatient attendance of 47,528 . It has a bed capacity of 50 with 8 doctors. The Comboni hospital has a laboratory that provides some microbiological services, including routine parasitological examinations, but does not perform bacterial culture and antibiotic sensitivity testing. The laboratory offers immunology, biochemistry, as well as haematology and transfusion services. The hospital receives referral cases from other health centres in the district.

\section{Study design}

We conducted a hospital-based prospective cross-sectional study from May to June 2014. Sampling involved two steps: (i) recruiting patients and interviewing them; and (ii) collecting study samples for laboratory investigations. The study participants comprised patients referred to the Comboni hospital for laboratory investigation of any type of sexually transmitted diseases (STD) whether or not they were sexually active. From this cohort, we investigated patients for T. vaginalis infections. Prior to the commencement of work, the research team conducted meetings with the Comboni hospital authorities, staff, and patients to explain the objectives of our study including benefits, potential risks and discomforts. $\mathrm{Pa}-$ tients were recruited based on willingness to fully participate and provision of written consent. Informed written consent were provided by patients before enrollment into the study. For patients aged $<18$ years, we sought for informed consent from parents or legal guardians as well as verbal consent by the patient to willingly partake in the study. Patients or legal guardians who provided informed consent also permitted that the data to be collected could be published in a peer-reviewed journal. A structured questionnaire (Additional file 1) was administered through interview to collect information on demographics, knowledge, attitudes and patients' practices that predispose them to T. vaginalis infections. Because patients were recruited at the laboratory, we conducted a physician-assisted work through of participants' hospital folders to ascertain signs and symptoms, confirm diagnosis and record treatment history. Patients on past (within 2 weeks) or current treatment for suspected sexually transmitted infections were excluded from study. Approval for the study (ID: MS-Et/M.5-P.3.3/2013-2014) was granted by the Ethical and Protocol Review Committee, University of Ghana Medical School, Korle-Bu.

\section{Sample collection and processing}

The primary outcome of the study was the detection of $T$. vaginalis in patients coming for STD checkup. Specimen collection and investigations were conducted following standard protocols but independent of the routine standard operative procedures for laboratory diagnosis of STD at the Comboni hospital. In our study, vaginal swabs were requested from females. Males provided urethral swabs. At the same time, about $15-20 \mathrm{~mL}$ of first catch urine samples were collected from both female and male participants. Swab specimen from each patient were agitated vigorously in $1 \mathrm{ml}$ of physiological saline $(0.85 \%)$. The urine samples were centrifuged at $1000 \mathrm{rpm}$ for $5 \mathrm{~min}$ and decanted to ensure the viability of trichomonads for wet mount microscopy. All patients who provided samples and accompanying data were de-identified and allotted arbitrary numbers to ensure anonymity. Patients found infected with parasites as well as those found with ailments not targeted by the project were referred to hospital for treatment.

\section{Wet mount microscopy}

Aliquot of the swab elute and decanted urine samples per patient were subjected to wet mount microscopy within $20 \mathrm{~min}$ after specimen collection. They were examined for motile trichomonads using $\times 100$ and $\times 400$ magnification. Three slides were prepared for each specimen to increase chances of recovering $T$. vaginalis. Trichomonas vaginalis was recorded as present if $\geq 1$ motile trichomonads were seen at any magnification.

\section{Rapid antigen test}

The JD Trichomonas vaginalis rapid tests were performed according to manufacturer's (Biotech ${ }^{\text {Tw }}$ Corp., 
China). Briefly, $0.5 \mathrm{~mL}$ of the swab elute was mixed in $0.5 \mathrm{~mL}$ of test buffer $(0.01 \%$ Tris- $\mathrm{Hcl}$ and $0.05 \% \mathrm{NaN} 3$, $\mathrm{PH}$ 7.5) for $10 \mathrm{~s}$. The JD's Trichomonas $\mathrm{V}^{\circ}$ test strip was placed in each mixed test buffer, and the result read visually after $15 \mathrm{~min}$. For urine sediments, $0.5 \mathrm{ml}$ of sample buffer was added to $0.5 \mathrm{~mL}$ of the sediments and mixed well for about $10 \mathrm{~s}$. For each urine-buffer test buffer, a JD's Trichomonas $\mathrm{V}^{\circ}$ test strip test strip was placed in the mixture, and the result read visually after $15 \mathrm{~min}$.

\section{Polymerase chain reaction tests}

Aliquots of swab elutes and urine specimens from each patient were separately placed in DNA guard (Biometrica, Co. USA) until further work-up. Polymerase chain reaction (PCR) targeting the beta-tubulin genes of $T$. vaginalis was used for the detection of the organism. The targeted genes encode the amino acid sequence of beta-tubulin protein, a major component of the T. vaginalis flagella and cytoskeleton [17]. The Qiagen DNA extraction kit (column method) was used to extract DNA. The primer set used was BTUB 9/2 [18] which targeted a conserved region of the beta-tubulin genes btub1, -2, and - 3 (GenBank accession numbers: btub1, L05468; btub2, L05469; and btub3, L05470) of T. vaginalis. The primer set was designed to amplify a DNA product of $112 \mathrm{bp}$ from the three beta-tubulin genes. We used the sequence of forward primer (BTUB 9, 5' CAT TGA TAA CGA AGC TCTTTA CGA T 3: positions 850 to 874 ) and reverse primer (BTUB 2, 5' GCA TGT TGT GCC GGA CAT AAC CAT 3': positions 961 to 938). A final volume of $25 \mu \mathrm{l}$ was used for PCR amplification reaction. This contained $10 \mu \mathrm{l}$ of DNA template, $0.625 \mu \mathrm{l}$ of each primer, $0.5 \mu \mathrm{l}$ of each of the four dNTPs (Sigma, Co. USA), $0.125 \mu \mathrm{l}$ of Taq polymerase (Biopioneers, Co. USA), $5 \mu$ lof PCR buffer (Biopioneers, Co. USA) and $6.625 \mu \mathrm{l}$ nuclease-free water. The following PCR conditions were used: an initial denaturing step of one minute at $95^{\circ} \mathrm{C}$ followed by 40 cycles of denaturation at $95^{\circ} \mathrm{C}$ for $45 \mathrm{~s}$, annealing at $52^{\circ} \mathrm{C}$ for $45 \mathrm{~s}$ and extension at $72^{\circ} \mathrm{C}$ for $1 \mathrm{~min}$ and then a final extension at $72^{\circ} \mathrm{C}$ for $2 \mathrm{~min}$. The PCR products were run on $2 \%$ agarose gel with ethidium bromide and visualized in visualized under ultraviolet trans-illuminator (JL Berker, Germany).

\section{Data analysis}

Data were entered into a Microsoft Excel spreadsheet and summarized using graphs and tables. Statistical analyses were performed using Epi info ${ }^{\text {тu}} 7$ statistical software package (CDC, Atlanta. The definitive consideration for $T$. vaginalis infection was positivity by PCR in any of two included patient specimens. Discrepant specimens (those with different results outcome for vaginal/urethral swab negative and urine samples) were determined to be $T$. vaginalis positive by performing PCR. The gold standard was PCR positivity. The diagnostic performance of detection methods was calculated by using the defined gold standard with confidence intervals based on normal approximation to binomial distribution. Agreement measures between detection methods was determined with Cohen's kappa tests. For descriptive statistics we calculated percentages with $95 \%$ confidence interval $(95 \% \mathrm{CI})$, mean \pm standard deviation (SD). Univariate comparisons were computed with Chi-square tests and unadjusted Odds ratios (OR) at 95\% confidence interval (CI). In multivariate analysis, logistic regression was conducted with adjusted odds ratios (AOR) using all variables that had $p<0.5$ in the univariate comparisons. Point estimates of statistical significance were indicated with 2 tailed $P$-values $<0.05$. Association between age and T. vaginalis was demonstrated with Locally Weighted Scatterplot Smoothing (LOESS) was generated using Tricube kernel smooth fit line with $60 \%$ of points to fit.

\section{Results}

Overall, 203 patients were eligible for inclusion. Of these, 150 provided informed consent and were enrolled in the study. There were 110 females and 40 male patients with a mean age of 28.67 years (ranging from 16 to 55 years). Out of this, $110(73.33 \%)$ were females with a mean age of 27.81 years (ranging from 16 to 50 years), and $40(26.67 \%)$ were males with a mean age of 31.05 years (ranging from 20 to 55 years). All included participants were sexually active. Among the female subjects, 45 (40.91\%) were pregnant. Genitourinary symptoms were observed in 81 of 150 patients (females,71; male, 10). The commonest symptoms associated with the included cases was genital discharge $(70.4 \%, n=57 / 81$, females, 54; males, 3), followed by itching in $61.7 \%$ (females, 49; males, 1) of the cases and painful micturition (females, 18; males, 8) in 32.1 of cases.

\section{Occurrence of $T$. vaginalis}

Table 1 shows the occurrence of $T$. vaginalis from patients' samples. A total of 300 samples (females: 110 vaginal swabs plus 110 urine samples; males: 40 urethral swabs and 40 urine samples) were received from study participants. Of the 300 samples tested, 127 were positive by at least one of the techniques used. None of the techniques could detect all positive samples. The PCR assay detected $T$. vaginalis positivity in 64 of 150 patients (42.6\%; 95\%CI:35.0, 50.6), and this was more prevalent in females $(n=53 / 110,48.1 \%$; $95 \%$ CI:39.1,57.2) than in males $(n=11 / 40,27.5 \%$; 95\%CI: 16.1,42.8). The PCR assay was positive for 10 of 30 males and negative for all females $(n=0 / 30)$ without genitourinary symptoms. Of the 150 subjects studied, 24 (16.0\%; 
Table 1 Detection of Trichomonas vaginalis in patients with Wet Mount Microscopy, JD's Trichomonas V® Rapid Antigen Test and PCR

\begin{tabular}{|c|c|c|c|c|c|c|}
\hline \multirow{3}{*}{$\begin{array}{l}\text { Patients and } \\
\text { specimens }\end{array}$} & \multicolumn{6}{|c|}{ Diagnostic methods } \\
\hline & \multicolumn{2}{|c|}{ Wet Mount Microscopy } & \multicolumn{2}{|c|}{ Rapid Antigen Test } & \multicolumn{2}{|l|}{ PCR } \\
\hline & No. & No. positive (\%) $\left[95 \% \mathrm{Cl}^{\mathrm{a}}\right]$ & No. & No. positive (\%) $[95 \% \mathrm{Cl}]$ & No. & No. positive (\%) $[95 \% \mathrm{Cl}]$ \\
\hline All patients & 150 & $24(16.0)[10.9,22.7]$ & 150 & $19(12.6)[8.3,18.9]$ & 150 & $64(42.6)[35.0,50.6]$ \\
\hline \multicolumn{7}{|l|}{ Gender } \\
\hline Females & 110 & $24(21.8)[15.1,30.4]$ & 110 & 15 (13.6) $[8.4,21.9]$ & 110 & $53(48.1)[39.1,57.2]$ \\
\hline Males & 40 & 0 & 40 & $4(10.0)[3.9,23.1]$ & 40 & $11(27.5)[16.1,42.8]$ \\
\hline All specimens & 300 & $25(8.3)[5.7,12.1]$ & 300 & $28(9.3)[6.5,13.2]$ & 300 & $127(42.3)[36.8,47.9]$ \\
\hline \multicolumn{7}{|l|}{ Specimen type } \\
\hline Vaginal swab & 110 & $23(20.9)[13.7,29.7]$ & 110 & 15 (13.6) [8.4, 21.9] & 110 & $53(48.1)[39.1,57.2]$ \\
\hline Female urine & 110 & $2(1.82)[0.5,6.4]$ & 110 & $9(8.1)[4.3,14.8]$ & 110 & $52(47.3)[38.2,56.5]$ \\
\hline Urethral swab & 40 & 0 & 40 & $4(10.0)[3.9,23.1]$ & 40 & $11(27.5)[16.1,42.8]$ \\
\hline Male urine & 40 & 0 & 40 & 0 & 40 & $11(27.5)[16.1,42.8]$ \\
\hline \multicolumn{7}{|c|}{ Without genitourinary symptoms } \\
\hline Females & 39 & $4(10.3)[4.1,23.6]$ & 39 & 0 & 39 & 0 \\
\hline Males & 30 & 0 & 30 & $4(13.3)[5.3,29.8]$ & 30 & 10 (33.3) [19.2-51.2] \\
\hline \multicolumn{7}{|c|}{ With genitourinary symptoms } \\
\hline Females & 71 & $20(28.1)[19.0,39.5]$ & 71 & $15(12.1)[13.3,33.7]$ & 71 & $53(74.6)[63.5,83.2]$ \\
\hline Males & 10 & 0 & 10 & 0 & 10 & 0 \\
\hline \multicolumn{7}{|l|}{ Genital discharge } \\
\hline Females & 54 & $14(21.1)[16.1,38.9]$ & 54 & $14(21.1)[16.1,38.9]$ & 54 & $38(70.3)[157.1,80.6]$ \\
\hline Males & 3 & 0 & 3 & 0 & 3 & 0 \\
\hline \multicolumn{7}{|c|}{ Itching around genital area } \\
\hline Females & 49 & $11(22.4)[13.1,35.8]$ & 49 & $14(28.5)[17.9,42.4]$ & 49 & $35(71.4)[57.6,82.9]$ \\
\hline Males & 1 & 0 & 1 & 0 & 1 & 0 \\
\hline \multicolumn{7}{|l|}{ Painful micturition } \\
\hline Females & 18 & $8(44.4)[25.6,66.3]$ & 18 & $10(55.5)[33.7,75.4]$ & 18 & $13(72.2)[49.1,87.5]$ \\
\hline Males & 8 & 0 & 8 & 0 & 8 & 0 \\
\hline \multicolumn{7}{|l|}{ Genital ulcers } \\
\hline Females & 5 & $4(80.0)[37.6,96.4]$ & 5 & $5(100.0)[56.5,100.0]$ & 5 & $5(100.0)[56.5,100.0]$ \\
\hline Males & 1 & 0 & 1 & 0 & 1 & 0 \\
\hline \multicolumn{7}{|l|}{ Burns } \\
\hline Females & 0 & 0 & 0 & 0 & 0 & 0 \\
\hline Males & 2 & 0 & 2 & 0 & 2 & 0 \\
\hline
\end{tabular}

${ }^{a}$ Clinical diagnosis, physician-assisted clinical summary/diagnosis; $\mathrm{Cl}$ confidence interval, VS high vaginal swab, UTI urinary tract infection, STI sexually transmitted infection, PID pelvic inflammatory disease, PCR Polymerase Chain Reaction; others, clinical diagnosis not related to genitourinary diseases and those without specific diagnosis

95\%CI:10.9, 22.7) were positive for $T$. vaginalis with wet mount microscopy. When data was stratified across gender, 24 of the 110 female subjects $(21.82$, 95\% CI $14.51,30.70)$ were positive for $T$. vaginalis compared to none for the male patients. The wet mount microscopy was positive for 4 of 39 females and negative for all males $(n=0 / 30)$ without genitourinary symptoms. The JD's Trichomonas $\mathrm{V}^{\oplus}$ test detected T. vaginalis in 19 (12.6\%; 95\%CI: 8.3, 18.9) of 150 participants- 15
(13.6\%; 95\%CI: $8.4,21.9)$ in 110 female patients and 4 (10.0\%; 95\%CI: 3.9,23.1) in 40 male patients. The rapid test was positive for 4 of 30 males and negative for all females $(n=0 / 39)$ without genitourinary symptoms.

\section{Sample type and test positivity}

We compared tests positivity of vaginal/urethral swabs and urine by wet mount microscopy, the JD's Trichomonas $\mathrm{V}^{\bullet}$ test and PCR assay. The PCR detected could 
detect all positive samples of wet mount microscopy and the JD's Trichomonas $\mathrm{V}^{\bullet}$ test. Of the 53 female patients with vaginal swabs positive for $T$. vaginalis by PCR, 52 also had urine samples positive for the parasite by the same technique. Similarly, all 11 male cases with urethral swab positive for $T$. vaginalis by PCR also had positive urine specimens for the parasite. For wet mount microscopy, 24 T. vaginalis cases were positive for 23 of 110 vaginal swabs compared to 2 of 110 urine samples. Only 1 patient had discrepant specimen (negative vaginal swab with positive urine sample). Both samples were determined by PCR to be positive for $T$. vaginalis. The JD's Trichomonas $\mathrm{V}^{\otimes}$ test had 6 female and 4 male patients with discrepant results. The test identified T. vaginalis in 15 of 110 vaginal swabs and 9 of corresponding urine samples. It also detected $T$. vaginalis in 4 of 40 urethral swabs but all the corresponding urine swabs were negative for the parasite. The discrepant samples were all $T$. vaginalis positive by PCR.

\section{Performance of diagnostic techniques}

The diagnostic performance of wet mount microscopy and the JD's Trichomonas $\mathrm{V}^{\oplus}$ test were compared using results of the PCR assay as gold standard (Table 2). Wet mount microscopy showed low sensitivity (31.6\%) but high specificity (100\%) with moderate to high positive predictive values (75.0\%) and positive likelihood ratio (3.0) for all patients. The microscopy recorded its best sensitivity score among asymptomatic (40.0\%) and female (39.2\%) patients. The least sensitivity $(0 \%)$ was noted for male patients. In comparison, there was weak agreement (Cohen's kappa, 0.283) between wet mount microscopy and PCR assay. The kappa improved to 0.533 only when asymptomatic cases were considered. Across all patients, the JD's Trichomonas $\mathrm{V}^{\circ}$ test displayed lower sensitivity $(25.0 \%)$ and specificity $(83.3 \%)$ compared to wet mount microscopy but with better positive predictive values (83.3\%) and positive likelihood ratios (5.0). A weak agreement (Cohen's kappa, 0.233) was noted between the rapid antigen test and PCR assay - and this was evident across all patient groups. Interestingly, although wet mount microscopy and the JD's Trichomonas $\mathrm{V}^{\circ}$ test had moderate to high specificities, their agreement was moderate (Cohen's kappa, 0.541).

\section{Univariate comparisons}

We compared patients' characteristics and their odds ratios (OR) by univariate analysis for potential risk factors of T. vaginalis infection. Trichomonas vaginalis infection was defined as test positivity to PCR assay for any of included patient's sample. The unadjusted odds

Table 2 Diagnostic performance of Mount Microscopy and JD's Trichomonas V ${ }^{\circledR}$ Rapid Antigen Assay compared to PCR in the detection of $T$. vaginalis among females

\begin{tabular}{|c|c|c|c|c|c|c|c|c|}
\hline \multirow[t]{3}{*}{ Diagnostics $^{a}$} & \multicolumn{8}{|l|}{ PCR } \\
\hline & \multirow{2}{*}{$\begin{array}{l}\text { Test }^{a} \\
\text { Pos.; Neg. }\end{array}$} & \multirow{2}{*}{$\begin{array}{l}\text { Percent } \\
\text { sensitivity } \\
(95 \% \mathrm{Cl})\end{array}$} & \multirow{2}{*}{$\begin{array}{l}\text { Percent } \\
\text { Specificity } \\
(95 \% \mathrm{Cl})\end{array}$} & \multicolumn{2}{|c|}{ Predictive values } & \multicolumn{2}{|c|}{ Likelihood ratio } & \multirow{2}{*}{$\begin{array}{l}\text { Cohen's Kappa } \\
\text { values }(95 \% \mathrm{Cl})\end{array}$} \\
\hline & & & & $\begin{array}{l}\text { Positive } \\
(95 \% \mathrm{Cl})\end{array}$ & $\begin{array}{l}\text { Negative } \\
(95 \% \text { Cl })\end{array}$ & Positive & Negative & \\
\hline Wet Mount Microscopy & $18 / 24 ; 87 / 126$ & $\begin{array}{l}31.6 \\
(20.3,45.3)\end{array}$ & $\begin{array}{l}93.5 \\
(85.9,97.3)\end{array}$ & $\begin{array}{l}75.0 \\
(52.9,89.4)\end{array}$ & $\begin{array}{l}69.1 \\
(60.1,52.5)\end{array}$ & $\begin{array}{l}3.0 \\
(1.4,6.2)\end{array}$ & $\begin{array}{l}0.45 \\
(0.34,0.59)\end{array}$ & $\begin{array}{l}0.283(70.0 \%) \\
(0.15,0.42)\end{array}$ \\
\hline Females & $18 / 24 ; 58 / 86$ & $\begin{array}{l}39.2 \\
(25.4,54.6)\end{array}$ & $\begin{array}{l}90.6 \\
(80.0,96.1)\end{array}$ & $\begin{array}{l}75.0 \\
(52.9,89.3)\end{array}$ & $\begin{array}{l}67.4 \\
(56.3,76.9)\end{array}$ & $\begin{array}{l}3 \\
(1.4,6.2)\end{array}$ & $\begin{array}{l}0.48 \\
(35.2,66.1)\end{array}$ & $\begin{array}{l}0.313 \\
(0.151,0.482)\end{array}$ \\
\hline Males & $0 / 0 ; 29 / 40$ & 0 & $\begin{array}{l}100 \\
(85.4,100)\end{array}$ & - & $\begin{array}{l}72.5 \\
(55.8,84.8)\end{array}$ & - & $\begin{array}{l}0.37 \\
(0.23-0.64)\end{array}$ & 0.00 \\
\hline Symptomatic patients & $14 / 20 ; 28 / 61$ & $\begin{array}{l}33.3 \\
(20.0,49.6)\end{array}$ & $\begin{array}{l}86.7 \\
(72.5,94.4)\end{array}$ & $\begin{array}{l}70.0 \\
(45.6,87.1)\end{array}$ & $\begin{array}{l}54.1 \\
(40.9,66.7)\end{array}$ & $\begin{array}{l}2.3 \\
(1.1,4.8)\end{array}$ & $\begin{array}{l}0.85 \\
(62.8,1.1)\end{array}$ & $\begin{array}{l}0.109 \\
(-0.057,0.276)\end{array}$ \\
\hline Asymptomatic patients & $4 / 4 ; 59 / 65$ & $\begin{array}{l}40.0 \\
(13.6,72.6)\end{array}$ & $\begin{array}{l}100 \\
(92.3,100)\end{array}$ & $\begin{array}{l}100 \\
(39.5,100)\end{array}$ & $\begin{array}{l}0.9 \\
(80.3,96.1)\end{array}$ & - & $\begin{array}{l}0.10 \\
(0.05-21.8)\end{array}$ & $\begin{array}{l}0.533 \\
(0.217,0.849)\end{array}$ \\
\hline Antigen Test & $15 / 19 ; 87 / 132$ & $\begin{array}{l}25.0 \\
(15.1,38.1)\end{array}$ & $\begin{array}{l}96.7 \\
(89.8,99.1)\end{array}$ & $\begin{array}{l}83.3 \\
(57.7,95.5)\end{array}$ & $\begin{array}{l}65.9 \\
(57.1,73.7)\end{array}$ & $\begin{array}{l}5.0 \\
(1.7,14.3)\end{array}$ & $\begin{array}{l}0.52 \\
(0.41,0.66)\end{array}$ & $\begin{array}{l}0.233 \\
(0.103,0.364)\end{array}$ \\
\hline Females & $13 / 15 ; 57 / 95$ & $\begin{array}{l}25.4 \\
(14.73,9.9)\end{array}$ & $\begin{array}{l}96.6 \\
(87.2,99.7)\end{array}$ & $\begin{array}{l}86.6 \\
(58.3,97.6)\end{array}$ & $\begin{array}{l}0.6 \\
(49.4,69.7)\end{array}$ & $\begin{array}{l}6.5 \\
(1.78,23.9)\end{array}$ & $\begin{array}{l}0.67 \\
(0.51,86.4)\end{array}$ & $\begin{array}{l}0.232 \\
(0.096,0.368)\end{array}$ \\
\hline Males & $3 / 4 ; 29 / 36$ & $\begin{array}{l}0.3 \\
(0.8,64.3)\end{array}$ & $\begin{array}{l}96.7 \\
(80.9,99.8)\end{array}$ & $\begin{array}{l}75.0 \\
(21.9,98.6)\end{array}$ & $\begin{array}{l}80.5 \\
(63.4,91.2)\end{array}$ & $\begin{array}{l}3 \\
(0.51,17.9)\end{array}$ & $\begin{array}{l}0.24 \\
(0.12,0.48)\end{array}$ & $\begin{array}{l}0.333 \\
(-0.001,0.667)\end{array}$ \\
\hline Asymptomatic patients & $3 / 4 ; 55 / 65$ & $\begin{array}{l}23.1 \\
(6.1,54.0)\end{array}$ & $\begin{array}{l}98.2 \\
(89.1,99.9)\end{array}$ & $\begin{array}{l}75.0 \\
(21.9,98.6)\end{array}$ & $\begin{array}{l}84.6 \\
(73.1,91.9)\end{array}$ & $\begin{array}{l}3 \\
(0.50,0.18)\end{array}$ & $\begin{array}{l}0.18 \\
(0.10,32.3)\end{array}$ & $\begin{array}{l}0.290 \\
(0.004,0.576)\end{array}$ \\
\hline Symptomatic patients & $13 / 15 ; 28 / 66$ & $\begin{array}{l}25.4 \\
(14.7,39.9)\end{array}$ & $\begin{array}{l}93.3 \\
(76.4,98.8)\end{array}$ & $\begin{array}{l}86.6 \\
(58.3,97.6)\end{array}$ & $\begin{array}{l}42.4 \\
(30.5,55.1)\end{array}$ & $\begin{array}{l}6.5 \\
(1.7,23.9)\end{array}$ & $\begin{array}{l}1.4 \\
(1.1,1.7)\end{array}$ & $\begin{array}{l}0.151 \\
(0.024,0.278)\end{array}$ \\
\hline
\end{tabular}

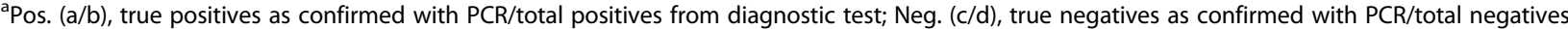
from diagnostic test; $C l$ confidence interval, $P C R$ polymerase chain reaction 
ratio of having a trichomonas infection was 2.45 (95\% CI, 1.11, 5.39; $P$-value $=0.026)$ when gender was female (Table 3). Being a minor, young adult or middle-aged adult was not associated with the occurrence of $T$. vaginalis infection. Regarding marital status, no significant association was observed between $T$. vaginalis infection and being married, divorced, or widowed. Rather, single patients were less likely to have $T$. vaginalis infection (OR,0.45; 95\%CI:0.23, 0.87; $P$-value $=0.021)$. The unadjusted odds ratio of having a trichomonas infection was $3.23(95 \%$ CI, 1.23, 8.48; $P$-value $=0.019)$ for uneducated subjects compared to those with any form of education. The following patient's characteristics were associated with a reduced likelihood of $T$. vaginalis infection: employment (OR, 0.14; 95\%CI:0.07, 0.30; $P$-value $<0.001)$, pregnancy (OR, 0.37; 95\%CI: 0.17, 0.70; $P$-value $=0.011)$. When data was analyzed using sexual health behaviours (Table 4), participants with knowledge of STI (OR, 0.08; 95\%CI:0.04, 0.19; $P$-value $<0.001$ ) or whose partners had no other sexual partners (OR, 0.09; 95\%CI:0.05, 0.31; $P$-value $<0.001)$ had significantly reduced odds of $T$. vaginalis infection. Similarly, subjects with no previous STI record (OR, 0.0.032; 95\%CI:0.01, 0.09; $P$-value $<0.001)$ or who had no sexual partners in the past 1 year (OR, 0.32; 95\%CI:0.13, $0.71 ; P$-value $<0.001)$ or were less likely to have the parasite.

\section{Multivariate risk factor analysis}

Overall 14 of 40 risk factor sub-levels included in the univariate analysis were significantly associated with $T$. vaginalis infection at the $p<0.05$ level (Table 4 ). The results of the multivariate analysis are presented in Table 5. After adjustment for all 14 factors in the in the final multivariate model, 3 variables were significantly associated with $T$. vaginalis infection. The strongest independent predictor for infection was the female gender (AOR, 24.89; 95\%CI: 10.58, 51.21; $P$-value< 0.001 ). Knowledge of STI showed a protective effect against $T$. vaginalis infection. Patients with knowledge of STI had a significantly reduced risk of infection (AOR, 0.13; 95\%CI: $0.07,0.29 ; \quad P$-value< 0.017$)$. Age was also

Table 3 Univariate analysis of patient's characteristics for potential risk factors of T. vaginalis infection

\begin{tabular}{|c|c|c|c|c|c|c|}
\hline \multirow[t]{2}{*}{ Covariates $^{a}$} & \multirow{2}{*}{$\begin{array}{l}\text { Patients } \\
(n= \\
150)\end{array}$} & \multicolumn{2}{|c|}{ Patients with $T$. vaginalis } & \multirow{2}{*}{$\begin{array}{l}\text { Unadjusted } \\
\text { Odds ratio }\end{array}$} & \multirow[t]{2}{*}{$95 \% \mathrm{Cl}$} & \multirow[t]{2}{*}{$P$-value } \\
\hline & & Yes $(n=64)$ & No $(n=86)$ & & & \\
\hline \multicolumn{7}{|l|}{ Demographics } \\
\hline Female gender & 110 & 53 & 57 & 2.45 & $1.11,5.39$ & 0.026 \\
\hline Age $( \pm S D)^{b}$ & & $31.12 \pm 12.12$ & $19.35 \pm 7.89$ & 2.03 & $1.06,3.92$ & 0.001 \\
\hline \multicolumn{7}{|l|}{ Age groups (years) } \\
\hline$<18$ (minors) & 10 & 6 & 4 & 2.12 & $0.57,7.85$ & 0.326 \\
\hline 18-35 (young adults) & 84 & 33 & 51 & 0.73 & $0.38,1.40$ & 0.406 \\
\hline 35-55 (middle-aged adults) & 56 & 25 & 31 & 1.14 & $0.58,2.18$ & 0.735 \\
\hline \multicolumn{7}{|l|}{ Locality } \\
\hline Inner town & 85 & 33 & 52 & 0.69 & $0.36,1.33$ & 0.318 \\
\hline Town outskirt & 33 & 19 & 14 & 2.17 & $0.99,4.75$ & 0.072 \\
\hline Village & 32 & 12 & 20 & 0.76 & $0.34,1.69$ & 0.551 \\
\hline \multicolumn{7}{|l|}{ Marital status } \\
\hline Single & 42 & 24 & 29 & 0.45 & $0.23,0.87$ & 0.021 \\
\hline Married & 63 & 22 & 33 & 0.84 & $0.43,1.65$ & 0.732 \\
\hline Divorced widowed & 23 & 11 & 12 & 1.57 & $0.65,3.83$ & 0.363 \\
\hline Pregnant & 45 & 12 & 33 & 0.371 & $0.17,0.79$ & 0.011 \\
\hline \multicolumn{7}{|l|}{ Education } \\
\hline None & 22 & 15 & 7 & 3.23 & $1.23,8.48$ & 0.019 \\
\hline Basic school & 59 & 20 & 39 & 0.55 & $0.27,1.07$ & 0.093 \\
\hline S.H.S & 37 & 13 & 24 & 0.66 & $0.31,1.42$ & 0.340 \\
\hline Tertiary & 32 & 16 & 16 & 1.40 & $0.64,3.06$ & 0.427 \\
\hline Employed & 85 & 20 & 65 & 0.143 & $0.07,0.30$ & $<0.001$ \\
\hline
\end{tabular}

${ }^{\mathrm{a}}$ T. vaginitis infection was defined with positivity to PCR diagnostic tests; SD standard deviation, Cl confidence interval, S.H.S Senior High School, STI sexually transmitted disease

${ }^{\mathrm{b}} \mathrm{Age}$ was considered as a continuous variable from 16 to 55 years 
Table 4 Univariate analysis of patients sexual and health characteristics for potential risk factors of T. vaginalis infection

\begin{tabular}{|c|c|c|c|c|c|c|}
\hline \multirow[t]{2}{*}{ Covariates $^{a}$} & \multirow{2}{*}{$\begin{array}{l}\text { Patients } \\
(n= \\
150)\end{array}$} & \multicolumn{2}{|c|}{ Patients with $T$. vaginalis } & \multirow{2}{*}{$\begin{array}{l}\text { Unadjusted } \\
\text { Odds ratio }\end{array}$} & \multirow[t]{2}{*}{$95 \% \mathrm{Cl}$} & \multirow[t]{2}{*}{$P$-value } \\
\hline & & Yes $(n=64)$ & No $(n=86)$ & & & \\
\hline Knowledge of STI & 96 & 22 & 74 & 0.08 & $0.04,0.19$ & $<0.001$ \\
\hline \multicolumn{7}{|l|}{ Previously had STI } \\
\hline No & 103 & 22 & 81 & 0.032 & $0.01,0.09$ & $<0.001$ \\
\hline Yes & 22 & 10 & 12 & 1.36 & $0.54,3.41$ & 0.634 \\
\hline No idea & 25 & 12 & 13 & 1.33 & $0.56,3.14$ & 0.658 \\
\hline Showed symptoms of STI & 81 & 20 & 61 & 0.17 & $0.08,0.35$ & $<0.001$ \\
\hline Genital discharge & 57 & 38 & 19 & 5.15 & $2.52,10.51$ & $<0.001$ \\
\hline Itching around genital area & 50 & 35 & 15 & 5.71 & $2.71,12.01$ & $<0.001$ \\
\hline Painful micturition & 26 & 13 & 13 & 1.43 & $0.61,3.34$ & 0.513 \\
\hline Genital ulcers & 6 & 5 & 1 & 7.20 & $0.82,63.25$ & 0.083 \\
\hline Urethral burns & 2 & 0 & 2 & 0 & - & 0.507 \\
\hline \multicolumn{7}{|c|}{ No. of sexual partners in past 1 year } \\
\hline 0 & 38 & 9 & 29 & 0.32 & $0.13,0.71$ & 0.007 \\
\hline 1 & 112 & 55 & 57 & 3.11 & $1.35,7.16$ & 0.007 \\
\hline \multicolumn{7}{|c|}{ Partner(s) had other sexual partner(s) in past 1 year } \\
\hline No & 89 & 20 & 69 & 0.09 & $0.05,2.13$ & $<0.001$ \\
\hline Yes & 28 & 15 & 13 & 1.72 & $0.75,3.93$ & 0.210 \\
\hline No idea & 23 & 13 & 10 & 1.93 & $0.79,4.75$ & 0.172 \\
\hline No condom use & 101 & 50 & 51 & 2.15 & $1.17,5.09$ & 0.021 \\
\hline Alcohol use & 44 & 9 & 35 & 0.87 & $0.344,2.22$ & 0.7775 \\
\hline Co-infection with yeast & 79 & 19 & 60 & 1.65 & $0.56,4.89$ & 0.3686 \\
\hline
\end{tabular}

${ }^{\mathrm{a}} T$. vaginitis infection was defined with positivity to PCR diagnostic tests; $C l$ confidence interval, STI sexually transmitted disease

significant risk factor for $T$. vaginalis infection. The multivariate analysis show that with every 1 year increase in age doubled the risk of infection with $T$. vaginalis $(\mathrm{AOR}=1.93,95 \% \mathrm{CI}: 1.11,3.90, p=0.011)$. The relationship between $T$. vaginalis infection and age was best described with a LOESS Tricube Kernel smooth fit line with local polynomial regression at 60\% (Fig. 1). The correlation between $T$. vaginalis and subject's age was more apparent in females and less dominant among the elderly.

Table 5 Multivariate analysis for risk factors of T. vaginalis infection

\begin{tabular}{lllll}
\hline Risk factor $^{a}$ & Level & $\begin{array}{l}\text { Adjusted } \\
\text { Odds Ratio }\end{array}$ & $95 \% \mathrm{Cl}$ & P-value \\
\hline Female gender & Yes/No & 24.87 & $10.55,51.19$ & 0.001 \\
Age $( \pm$ SD) & 1 year increase & 1.41 & $1.09,3.54$ & 0.013 \\
Knowledge of STI & Yes/No & 0.16 & $0.08,0.31$ & 0.014 \\
\hline
\end{tabular}

${ }^{a}$ The predictive accuracy of the models evaluated by Hosmer and Lemeshow goodness-of-fit test was non-significant with $P$-value $>0.05$ suggesting that the model predicted accurately on average. The discriminatory power of the multiple logistic regression analysis as measured by the area under the ROC curve was 0.791 . Stepwise modelling was adjusted for univariate variables with $P$-value $<0.05$

\section{Discussion}

Routine attempts towards the detection and treatment of Trichomoniasis has gained prominence owing to its recent association with $\mathrm{HIV}$, adverse gynaecological and obstetric outcomes and infertility [19-22]. Trichomonas infection attracts little attention in sub-Sahara Africa perhaps because most infected people do not show any symptoms and when left untreated serve as asymptomatic carriers [22, 23]. Poor diagnostic techniques for $T$. vaginalis also compounds the burden.

In this study, 150 patients visiting the laboratory for STI check-up were examined for $T$. vaginalis and among these, 64 (42.6\%) were positive by PCR assay. There were two major findings. First, the prevalence of $T$. vaginalis infection is indeed high. Although this could be due to our select patient group, it is also an indication of the existence of the infection in the study region. This high prevalence is probably due to the fact that, the $T$. vaginalis problem has long existed in our community, and the lack of awareness and routine laboratory detection may have compounded the problem. Second, the results of the present study point to $T$. vaginalis as being prevalent among even males with no 


\section{$\leftarrow$ females $\rightarrow$ males}

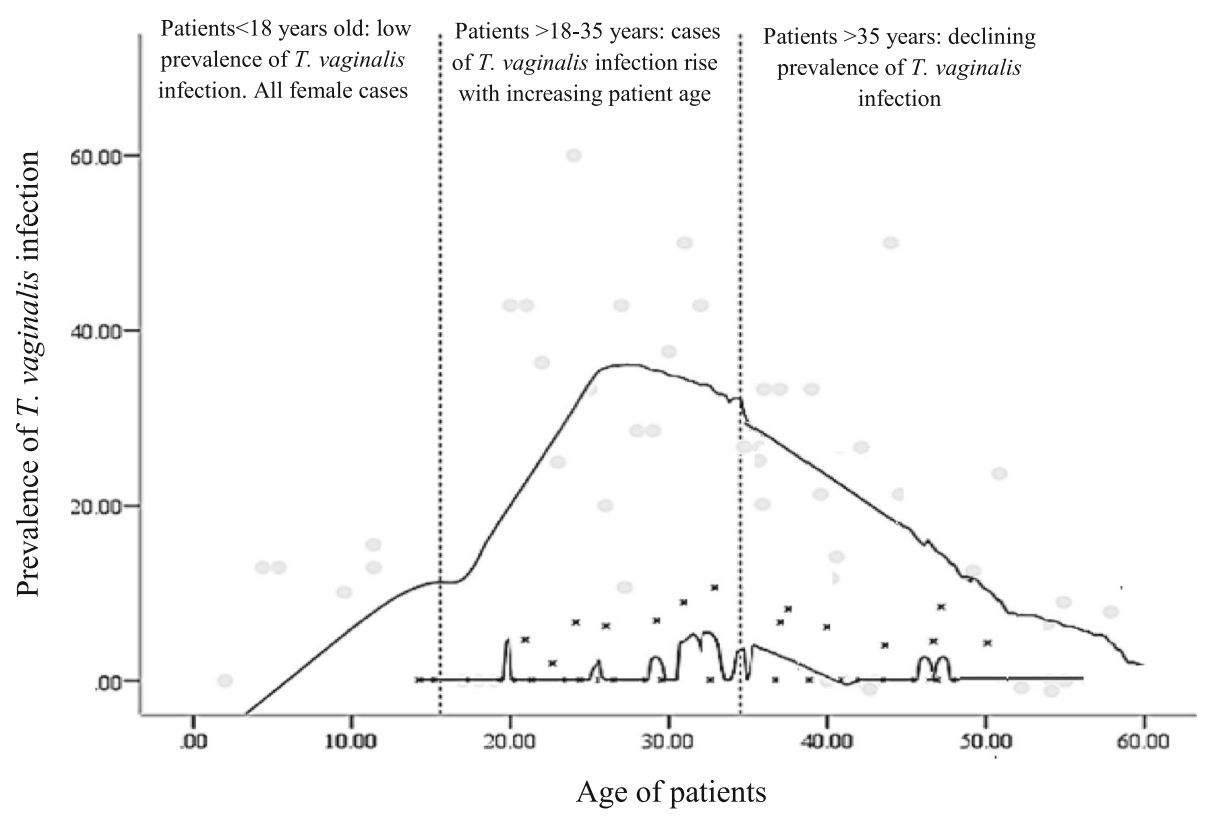

Fig. 1 Profile of Trichomonas vaginalis prevalence across patients' age with Tricube Kernel smooth fit line generated with local polynomial regression at $60 \%$ of points to fit. Over the period of study, T. vaginalis cases were predominant in females. There is apparent relationship between age and infection prevalence among females that peaks at approximately age 26 years

genitourinary symptoms and not just females. It is very difficult to predict the $T$. vaginalis infection without clinical findings, as in our study only $33 \%(n=10 / 30)$ and none $(n=0 / 39)$ respectively of the male and female patients with no genitourinary findings were positive for $T$. vaginalis. Overall, $T$. vaginalis positivity was high (48.3\%) among female. The female gender also constituted significant risk factor for $T$. vaginalis with increased infection odds of 24.9 (Table 5). The prevalence obtained for females in this study is slightly above the WHO estimate (18.12\%) in the African region [1] although high sensitive detection methods were included in the latter. The prevalence of $T$. vaginalis has generally been considered to be low among men, with a global prevalence of $1-5 \%[1,24,25]$. The variation in prevalence observed between males and females is attributed to biological differences, particularly oestrogen, between gender. Also availability of iron [26] may facilitate persistent $T$. vaginalis infection among females during reproductive years.

In communities with prevalent $T$. vaginalis infections, an ideal detection test must have the greatest ability to pick true positives without selecting false negatives. Our results concerning $T$. vaginalis diagnosis demonstrated poor agreement between PCR assay as gold standard and the wet mount microscopy or JD's Trichomonas $\mathrm{V}^{\bullet}$ test. Two observations merit attention. First, both wet mount microscopy and JD's Trichomonas $\mathrm{V}^{\bullet}$ test tests recorded low sensitivities albeit with moderate to high specificities. It is noteworthy that, a certain proportion of false positives is often acceptable if the sensitivity margins are signicantly high. Yet, our wet mount microscopy could only detect 25 of $64 \mathrm{~T}$. vaginalis positives and the rapid tests, 28 of 64 T. vaginalis positives. The negative likelihood ratios for both tests ranged between 0.1 through 0.52 depending on the patient population. Such low detection rates are more apt to frequent misdiagnosis and underestimation of the $T$. vaginalis problem. Second, in the search for less invasive human samples for detection of $T$. vaginalis, researchers have evaluated the possible use of urine specimens $[14,27]$. In this current study, we found no discrimination in PCR test results between vaginal/urethral swabs and urine samples. Rather, extremely poor diagnostic outcomes were observed for wet mount microscopy and JD's Trichomonas $\mathrm{V}^{\circ}$ test performed with urine samples as opposed to vaginal/urethral swabs. The addition of urine did not significantly improve the T. vaginalis detection.

It has been emphasized that routine implementation of the PCR test should be used for T. vaginalis diagnosis. But the detection of $T$. vaginalis by PCR in microbiology laboratories remains a contentious issue with some experts questioning its clinical relevance in view of the financial demands involved. More so the strategy involves the use of skilled expertise. In contrast, expert 
microscopy is abundant sub-Saharan Africa and easily adapted in microbiology laboratories for diverse routine work. It remains the conventional detection method for routine diagnosis of parasites in STI across many sub-Saharan African countries. The results however suggest that wet mount microscopy may have low ability in our subset population to discriminate between those individuals with the disease and without the disease. The finding agrees well with submissions by other researchers $[14,28]$. The JD's Trichomonas $\mathrm{V}^{\circ}$ test did not appear to be a better alternative either. Suffice to say that the poor performance of the rapid antigen test contrasts the higher sensitivity (100\%) reported elsewhere [29] but the basis if this discrepancy is unknown.

The spectrum of selected patient population affects the prevalence of studies. In multivariate logistic analysis, we noted knowledge of STI to be protective against $T$. vaginalis and that this pattern was associated with increasing age and is prevalent among the female gender. Nearly a third of participants had no knowledge of STI. Perhaps the high occurrence of $T$. vaginalis could be attributed to lack of awareness and ignorance of the public health implication of the infection. This observation should however be interpreted with the awareness that a greater proportion of females than males consented to participate in the study. This may have overemphasized the T. vaginalis burden.

\section{Conclusion}

In conclusion, the sensitivity of wet mount microscopy was low, thus it is unreliable for Trichomoniasis screening among patients in our region. However, given that a negative wet mount does not rule out the infection with T. vaginalis, we suggest a mandatory $\mathrm{PCR}$ assay as gold standard laboratory method for confirmation of negative results. The JD's Trichomonas $\mathrm{V}^{\bullet}$ test should not be considered as an alternative test.

\section{Abbreviations}

Cl: Confidence Interval; HVS: High vaginal swab; PCR: Polymerase chain reaction; PID: Pelvic inflammatory disease; STI: Sexually transmitted disease; T. vaginalis: Tricchomonas vaginalis; U/S: Urethra swab; UTI: Urinary tract disease

\section{Acknowledgements}

We are grateful to the following for their support: Sogakope District Assembly Office, staff of the Comboni hospital and microbiology laboratory.

\section{Funding}

This study was supported with grant from the postgraduate research fund at the University of Ghana college of Health Sciences. The funding agency had no influence on the design of the study; the collection, analysis, and interpretation of data; and the writing of the manuscript.

\section{Availability of data and materials}

The datasets used and/or analysed during the current study are available from the corresponding author on reasonable request.

\section{Authors' contributions}

AFP, RFG, RHA, NON conceived the study; participated in its design, coordination, and collation of laboratory data. NON, GAM, BH, helped in collation of data, performed the statistical analysis and helped to draft the manuscript. MC, LA participated in the study design and coordination and helped to draft the manuscript. All authors read and approved the final manuscript

\section{Ethics approval and consent to participate}

The Ethical Review and Protocol Committee of the University of Ghana Medical School, Korle-Bu provided approval to conduct this study (Ethical/ Protocol Approval Number: MS-Et/M.S-P.3.3/2013-2014). Prior to the commencement of work, the research team conducted meetings with the Comboni hospital authorities and staff to explain the objectives of our study including benefits, potential risks and discomforts. Informed written consent were provided by patients before enrollment into the study. Patients who provided informed consent also permitted that the data to be collected could be published in a peer-reviewed journal. All patients who provided samples and accompanying data were de-identified and allotted arbitrary numbers to ensure anonymity. Patients found infected with parasites as well as those found with ailments not targeted by the project were referred to hospital for treatment.

\section{Consent for publication}

Not applicable.

\section{Competing interests}

The authors declare that they have no competing interests.

\section{Publisher's Note}

Springer Nature remains neutral with regard to jurisdictional claims in published maps and institutional affiliations.

\section{Author details}

${ }^{1}$ Department of Medical Laboratory Sciences, School of Biomedical and Allied Health Sciences, University of Ghana, Korle-bu, Accra, Ghana. ${ }^{2}$ School of Life Sciences, University of Nottingham, Nottingham, UK. ${ }^{3}$ Camboni Catholic Hospital, Sogakope, Ghana.

Received: 27 February 2017 Accepted: 10 December 2018

Published online: 27 December 2018

\section{References}

1. WHO. Prevalence and incidence of selected sexually transmitted infections, Chlamydia trachomatis, Neisseria gonorrhoeae, syphilis and Trichomonas vaginalis: Methods and results used by WHO to generate 2005 estimates. 2011.

2. Tabrizi SN, Paterson BA, Fairley CK, Bowden FJ, Garland SM. Comparison of tampon and urine as self-administered methods of specimen collection in the detection of Chlamydia trachomatis, Neisseria gonorrhoeae and Trichomonas vaginalis in women. Int J STD AIDS. 1998;9:347-9.

3. Cotch MF, Pastorek JG, Nugent RP, Hillier SL, Gibbs RS, Martin DH, et al. Trichomona vaginalis associated with low birth weight and preterm delivery. Sex Transm Dis. 1997;24:353-60.

4. Petrin D, Delgaty K, Bhatt R, Garber G. Clinical and microbiological aspects of Trichomonas vaginalis. Clin Microbiol Rev. 1998;11:300-17.

5. CDC. Trichomoniasis: CDC fact sheet [Internet]. Am. Fam. Physician. 2007 [cited 2017 Jun 4]. p. 1-2. Available from: http://www.cdc.gov/std/ Trichomonas/Trichomoniasis-Fact-Sheet.pdf.

6. Lee JJ, Moon HS, Lee TY, Hwang HS, Ahn M, Ryu J. PCR for diagnosis of male Trichomonas vaginalis infection with chronic prostatitis and urethritis. Korean J Parasitol. 2012;50:157-9.

7. Sorvillo F, Smith L, Kerndt P, Ash HL. Trichomonas vaginalis, HIV, and African-Americans. Emerg Infect Dis. 2001;7:927-32.

8. Mcclelland RS, Sangare L, Hassan WM, Lavreys L, Mandaliya K, Kiarie J, et al. Infection with Trichomonas vaginalis increases the risk of HIV-1 acquisition. J Infect Dis. 2007;195:698-702.

9. Sutton M, Sternberg M, Koumans EH, McQuillan G, Berman S, Markowitz L. The prevalence of Trichomonas vaginalis infection among reproductive-age women in the United States, 2001-2004. Clin Infect Dis. 2007;45:1319-26. 
10. Khalaf AK, Kadhim KJ. Use TVK 3 / 7 gene as a target to detect Trichomonas vaginalis from urine of women in southern Iraq. TQMJ. 2010;4:36-46.

11. Crosby R, DiClemente RJ, Wingood GM, Harrington K, Davies SL, Hook EWI, et al. Predictors of infection withTrichomonas vaginalis : a prospective study of low income African-American adolescent females. Sex Transm Infect. 2002;78:360-4.

12. Adu-Sarkodie Y, Opoku BK, Crucitti T, Weiss HA, Mabey D. Lack of evidence for the involvement of rectal and oral trichomonads in the aetiology of vaginal trichomoniasis in Ghana. Sex Transm Infect. 2007;83:130-2.

13. Adu-Sarkodie Y, Opoku BK, Danso KA, Weiss HA, Mabey D. Comparison of latex agglutination, wet preparation, and culture for the detection of Trichomonas vaginalis. Sex Transm Infect. 2004;80:201-3.

14. Lawing LF, Hedges SR, Schwebke JR. Detection of Trichomonosis in vaginal and urine specimens from women by culture and PCR. J Clin Microbiol. 2000:38:3585-8.

15. Wendel KA, Erbelding EJ, Gaydos CA, Rompalo AM. Trichomonas vaginalis polymerase chain reaction compared with standard diagnostic and therapeutic protocols for detection and treatment of vaginal Trichomoniasis. Clin Infect Dis. 2002;35:576-80.

16. Ghana Statistical Service. Ghana Demographic and Health Survey 2014: Ghana statistical service, Ghana health service,. Ghana Stat Serv Ghana Demogr Heal Surv 2014

17. Katiyar SK, Edlind TD. $\beta$-tubulin genes of Trichomonas vaginalis. Mol Biochem Parasitol. 1994;64:33-42.

18. Madico G, Quinn TC, Rompalo A, Mckee KT, Gaydos CA. Diagnosis of Trichomonas vaginalis infection by PCR using vaginal swab samples. J Clin Microbiol. 1998;36:3205-10.

19. Muzny C, Burkholder G, Austin E, Schwebke J. 8: Missed opportunities for trichomonas vaginalis diagnosis and treatment at an urban HIV clinic. Am J Obstet Gynecol. 2015;213:886 Available from: https://inkinghub.elsevier. com/retrieve/pii/S000293781501039X.

20. Muzny CA, Burkholder GA, Fry KR, Austin EL, Schwebke JR. Trichomonas vaginalis Nucleic Acid Amplification Testing at an Urban HIV Clinic. Sex. Transm. Dis; 2016. p. 483-8.

21. Salawu OT, Esume CN. Frequency of human immunodeficiency virus (HIV) in Trichomonas vaginalis infected women in Badagry, Lagos. Nigeria J Reprod Infertil. 2016;17:61-3.

22. Davis A, Dasgupta A, Goddard-Eckrich D, El-Bassel N. Trichomonas vaginalis and human immunodeficiency virus coinfection among women under community supervision: a call for expanded T. Vaginalis screening. Sex Transm Dis. 2016;43:617-22.

23. Muzny CA, Rivers CA, Austin EL, Schwebke JR. Trichomonas vaginalis infection among women receiving gynaecological care at an Alabama HIV clinic. Sex Transm Infect. 2013:89:514-8.

24. Gaydos CA, Barnes MR, Quinn N, Jett-goheen M, Hsien Y-H. Trichomonas vaginalis infection in men who submit self-collected penile swabs after internet recruitment. Sex Transm Infect. 2013;89:504-8.

25. Rogers SM, Turner CF, Hobbs M, Miller WC, Tan S, Roman AM, et al. Epidemiology of undiagnosed Trichomoniasis in a probability sample of urban young adults. PLoS One. 2014;9:e90548.

26. Poole DN, McClelland RS. Global epidemiology of Trichomonas vaginalis. Sex Transm Infect. 2013;89:418-22.

27. Blake DR, Duggan A, Joffe A. Use of spun urine to enhance detection of Trichomonas vaginalis in adolescent women. Arch Pediatr Adolesc Med. 1999;153:1222-5

28. Van Der Schee C, Van Belkum A, Zwijgers L, Van Der Brugee E, O'Neill EL, Luijendijk AD, et al. Improved Diagnosis of Trichomonas vaginalis Infection by PCR Using Vaginal Swabs and Urine Specimens Compared to Diagnosis by Wet Mount Microscopy, Culture, and Fluorescent Staining. J Clin Microbiol. 1999;37:4127-30.

29. Piperaki. ET, Theodora. M, Mendris. M, Barbitsa. L, Pitiriga. L, Patili. D, et al. Comparison of four methods for the detection of Trichomonas vaginalis infection in symptomatic and asymptomatic women in Athens, Greece. Clin. Microbiol. Infect. [Internet]. 2010;16:S687.

Ready to submit your research? Choose BMC and benefit from:

- fast, convenient online submission

- thorough peer review by experienced researchers in your field

- rapid publication on acceptance

- support for research data, including large and complex data types

- gold Open Access which fosters wider collaboration and increased citations

- maximum visibility for your research: over $100 \mathrm{M}$ website views per year

At BMC, research is always in progress.

Learn more biomedcentral.com/submissions 